\title{
Voltammetric determination of heavy metals in honey bee venom using hanging mercury drop electrode and PLA/carbon conductive filament for 3D printer
}

\author{
Marta Choinska ${ }^{1,2} \cdot$ Vojtěch Hrdlička $^{1}$ [D Ivana Šestáková ${ }^{1}$ Tomáš Navrátil ${ }^{1}$
}

Received: 9 November 2020 / Accepted: 19 December 2020 / Published online: 16 January 2021

(c) Springer-Verlag GmbH Austria, part of Springer Nature 2021

\begin{abstract}
A new method for determination of selected heavy metals $(\mathrm{Cd}, \mathrm{Pb}, \mathrm{Cu}, \mathrm{Zn}$, and $\mathrm{Ni}$ ) in honey bee venom was developed. Heavy metals are metabolized and incorporated into bee products, including honey and honey bee venom (apitoxin). Their composition reflects contamination of "bee environment", providing information about heavy metal contamination in the neighborhood of human dwellings. Moreover, assessment of bee products contamination is relevant for medicine, as they are a tool for promising therapeutic and chemoprophylactic strategies against COVID-19 (SARS-CoV-2). Owing to the complicated matrix, the developed method consists of wet mineralization with sulfuric acid, nitric acid, under increased temperature, and pressure and subsequent repeated boiling with concentrated nitric acid. Determination of the selected metals was carried out by anodic or cathodic stripping voltammetry on two types of electrodes: pen-type hanging mercury drop electrode (HMDE) and PLA filament with carbon conductive admixture (PLA-C) for 3D printer. Contents of lead and cadmium in all analyzed bee venom samples were on the level of $\mathrm{mg} \mathrm{kg}^{-1}$, of nickel and copper about ten times higher, and of zinc on the level of $\mathrm{g} \mathrm{kg}^{-1}$. The results achieved using HMDE were recorded with average relative standard deviation (RSD) 5.4\% (from 3.2\% to $8.6 \%$ ) and using PLA-C $11.8 \%$ (from $6.5 \%$ to $18.0 \%$ ). The results achieved using both electrodes proved to be equivalent with statistical probability higher than $95 \%$.
\end{abstract}

Graphic abstract

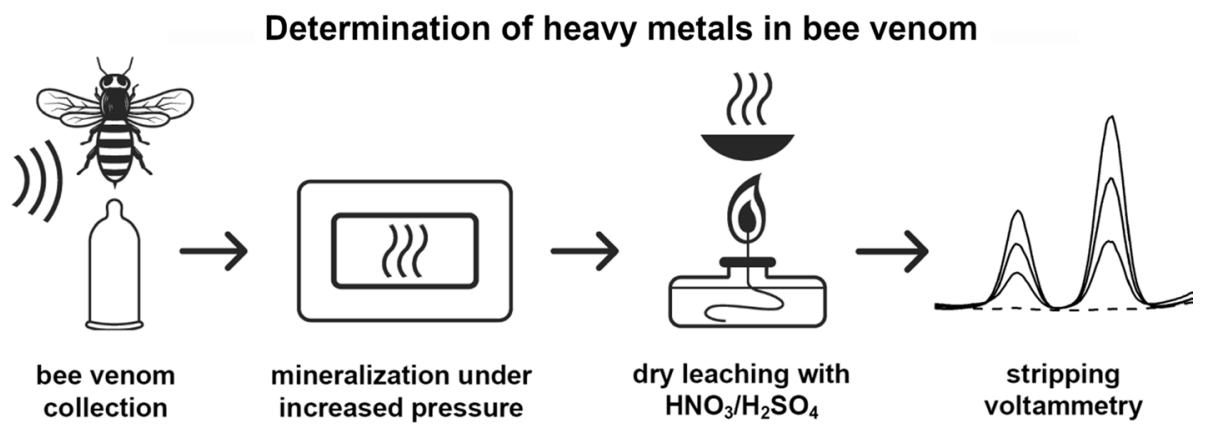

Keywords Honeybee venom $\cdot$ Heavy metals $\cdot$ Anodic stripping voltammetry $\cdot$ Mineralization $\cdot$ Pen-type hanging mercury drop electrode $\cdot$ PLA filament with carbon conductive admixture (PLA-C) for 3D printer

Vojtěch Hrdlička

Vojtech.hrdlicka@jh-inst.cas.cz

Extended author information available on the last page of the article

\section{Introduction}

Honey bee venom is secreted by honey bee (Hymenoptera) workers or queens (not drones). Reported lethal dose (LD50) for humans is about $2.8-3.5 \mathrm{mg} / \mathrm{kg}$ (400-1500 stingers), LD50 mouse i.v. $=0.6 \mathrm{mg} \mathrm{kg}^{-1}$ [1-3]. Dried bee venom is 
a very fine, lightly yellow powder. It is partially soluble in water forming an opalescent solution. Its composition is as follows (percentages represent the proportion of the substance in the dry matter) $[1,4]$ :

- $50-55 \%$ strongly basic polypeptide melittin (damages red and white blood cells, pain-producing substance), 2-3\% apamin (affects the central nervous system), mast cell degranulating (MCD) peptide (disrupts cell membrane activity);

- Enzymes: $13-14 \%$ phospholipase A2 and B, 2-3\% hyaluronidase;

- Biogenic amines: histamine, dopamine, norepinephrine.

Honey bee venom also contains substances with which the bees come into contact during their lifetime, including heavy metals that contaminate the environment. The analysis of honey bee venom living in particular area therefore provides information on the pollution therein. Moreover, information on contamination of bee products may be of great importance in medicine, as they may be a tool for promising therapeutic and chemoprophylactic strategies against COVID-19 (SARS-CoV-2) [5-8]. Other potential applications of honey bee venom are in the treatment arthritis, cancerous, and autoimmune diseases [9].

Anodic (ASV) and cathodic (CSV) stripping voltammetry were chosen for this study due to their speed, selectivity, and sensitivity. Voltammetric (and formerly polarographic) methods for determination of heavy metals $(\mathrm{Pb}, \mathrm{Cd}, \mathrm{Cu}$, $\mathrm{Zn}, \mathrm{Ni}$, generally metals with density above $5000 \mathrm{~kg} \mathrm{~m}^{-3}$ [10]) are widely used and well documented for a variety of matrices [11, 12]. Determination of these heavy metals in biological matrices is complicated, because they are bound or incorporated in organic molecules in various ways (e.g., in the "defense molecules of the organism"-metallothioneins and phytochelatins [13-15] or in low molecular weight organic acids that affect the transport of metals across biological membranes [14-19]).

Voltammetric methods can be utilized for speciation analysis, ergo to reveal the incorporation of heavy metals into the above-mentioned molecules as well as for determination of total heavy metal content, i.e., both free and bound forms. For determination of the total content, it is necessary to release the metal ions from complex structures of the matrix, possibly with a suitable mineralization process [20-24]. These processes are difficult to automate, as they are frequently composed of various, mostly human operated steps, which are specific for a particular matrix. The mineralization procedure is time consuming and often longer than voltammetric analysis itself.

The use of hanging mercury drop electrodes (HMDEs) or silver solid amalgam electrodes (AgSAEs) for the subsequent determination of heavy metal content in properly digested organic matrix is a straightforward process. Analytical performances of these electrodes are comparable [25] with very low limits of detection (LODs), even in comparison with modern spectrometric methods [25]. Mostly unsubstantiated fears of mercury toxicity and strict regulations [26-28] led to the development of alternative electrode materials.

Filaments for 3D printing with addition of a conductive phase are among the most promising materials for fabrication of customized electrochemical sensors or even complete voltammetric cells according to the requirements (size, shape, arrangement, etc.) of the user [29-32]. Electrochemical properties (sensitivity, signal to noise ratio, kinetics of electron transfer, etc.) of these commonly available filament electrodes are generally not as good as in the case of mercury-based electrodes, although often sufficient for intended purpose [33]. In this study, we compare an electrode made of conductive 3D printer filament with more traditional HMDE in the context of trace analysis of $\mathrm{Pb}, \mathrm{Cd}, \mathrm{Cu}, \mathrm{Zn}$, and $\mathrm{Ni}$ in honey bee venom. The aim of this study is development and optimization of a new method for determination of selected heavy metals with the use of stripping voltammetry in honey bee venom, including sample pretreatment by mineralization.

\section{Results and discussion}

Six samples of honey bee venom supplied by Food Research Institute Prague, denoted as S1, S2, S3, S4, S5, and S6, were analyzed.

\section{Development of sample digestion procedure}

None of the analyzed samples could be completely dissolved in distilled water or in sulfuric, nitric, or hydrofluoric acid without a preliminary treatment. The untreated venom solution was always slightly opalescent with white-gray precipitate at the bottom of the flask. Therefore, various methods of sample digestion were tested (some of them are listed in Table 1:

- Repeated dissolution in oxidizing acids (concentrated sulfuric and nitric acids) and evaporation to dryness;

- Boiling with above-mentioned acids;

- Dry ashing;

- Wet digestion with sulfuric acid, nitric acid, under increased temperature and pressure;

- Combinations of the above-mentioned procedures.

Neither dry ashing by incineration in the furnace nor microwave digestion led to complete dissolution of the 
Table 1 Comparison of tested honey bee venom digestion procedures. Weighted sample $0.2000 \pm 0.0025 \mathrm{~g}$

\begin{tabular}{lllllll}
\hline $\mathrm{HNO}_{3} / \mathrm{cm}^{3}$ & $\mathrm{H}_{2} \mathrm{SO}_{4} / \mathrm{cm}^{3}$ & $\begin{array}{l}\text { Pressure } \\
\text { decomp }\end{array}$ & Temperature $/{ }^{\circ} \mathrm{C}$ & $\begin{array}{l}\text { Time of } \\
\text { decomp./h }\end{array}$ & $\begin{array}{l}\text { No. of evaporations/ } \\
\mathrm{HNO}_{3} / \mathrm{cm}^{3} / \mathrm{H}_{2} \mathrm{SO}_{4} /\end{array}$ & Dry ashing \\
$\mathrm{cm}^{3}$
\end{tabular}

Optimum conditions are denoted in bold font venom sample. Similarly, repeated evaporation to dryness after addition of nitric acid, sulfuric acid, and even hydrofluoric acid or in combination with incineration wasn't sufficient. Therefore, wet pressure digestion under increased temperature using the mineralizer "Laboratory equipment ZA-1 for pressure decomposition of sample" was included. $0.2000 \pm 0.0025 \mathrm{~g}$ of venom sample was transferred into Teflon container (wall thickness $0.3 \mathrm{~cm}$ ) and various amounts of sulfuric and nitric acids were added (see Table 1). However, the contamination of blank solutions by heavy metals with the use of wet pressure decomposition was significant. This was caused by acid vapors, which penetrate the Teflon walls of the mineralizer container at temperatures above $130{ }^{\circ} \mathrm{C}$, causing corrosion of mineralizer steel walls and of its other metallic parts (e.g., pressure springs). The released metals consequently penetrate the thin Teflon walls and contaminate the mineralized sample. Therefore, a new Teflon container with a wall and cover thickness of $1 \mathrm{~cm}$ was constructed in our laboratory.

The mineralizates obtained by wet pressure decomposition were afterwards repeatedly boiled with sulfuric and nitric acid and evaporated to dryness. Finally, on the base of performed experiments, the optimum digestion procedure, suitable for all tested venom samples, was as follows: $0.2 \mathrm{~g}$ of bee venom was transferred into the mineralizer, 3 $\mathrm{cm}^{3}$ of concentrated nitric acid and $1 \mathrm{~cm}^{3}$ of concentrated sulfuric acid were added. The mineralizer was placed into laboratory oven heated up to $140{ }^{\circ} \mathrm{C}$ for $4 \mathrm{~h}$. The resulting mineralizate was afterwards evaporated to dryness, 1.5 $\mathrm{cm}^{3}$ of concentrated nitric acid and $1 \mathrm{~cm}^{3}$ of concentrated sulfuric acid were added and the solution was repeatedly boiled and evaporated to dryness. These boiling and evaporation processes have to be repeated at least 10 times (until a white or transparent residue is formed). The resulting residue was completely dissolved in deionized water and $\mathrm{pH}$ value adjusted for a particular voltammetric experiment as described in the Experimental section.

\section{Determination of heavy metals using HMDE}

The results of heavy metal $(\mathrm{Cd}, \mathrm{Pb}, \mathrm{Cu}, \mathrm{Zn}$, and $\mathrm{Ni})$ determinations at HMDE are summarized in Table 2. The metals

Table 2 Concentrations of heavy metals in honey bee venom; determinations were repeated five times

\begin{tabular}{|c|c|c|c|c|c|c|c|c|c|c|}
\hline & $\mathrm{Pb} / \mathrm{mg} \mathrm{kg}^{-1}$ & $\mathrm{RSD} / \%$ & $\mathrm{Cd} / \mathrm{mg} \mathrm{kg}^{-1}$ & $\mathrm{RSD} / \%$ & $\mathrm{Cu} / \mathrm{mg} \mathrm{kg}^{-1}$ & $\mathrm{RSD} / \%$ & $\mathrm{Zn} / \mathrm{mg} \mathrm{kg}^{-1}$ & $\mathrm{RSD} / \%$ & $\mathrm{Ni} / \mathrm{mg} \mathrm{kg}^{-1}$ & $\mathrm{RSD} / \%$ \\
\hline S1 & $4.97 \pm 0.22$ & 3.6 & $3.04 \pm 0.27$ & 7.2 & $22.8 \pm 1.2$ & 4.2 & $993 \pm 75$ & 6.1 & $20.4 \pm 1.4$ & 5.4 \\
\hline $\mathrm{S} 2$ & $4.48 \pm 0.31$ & 5.6 & $3.24 \pm 0.30$ & 7.5 & $20.9 \pm 1.1$ & 4.4 & $1033 \pm 78$ & 6.1 & $19.51 \pm 0.61$ & 2.5 \\
\hline S3 & $3.59 \pm 0.28$ & 6.4 & $0.429 \pm 0.040$ & 7.4 & $18.7 \pm 1.2$ & 5.1 & $1420 \pm 58$ & 3.3 & $11.90 \pm 0.56$ & 3.8 \\
\hline S4 & $3.06 \pm 0.30$ & 8.1 & $0.361 \pm 0.038$ & 8.6 & $19.41 \pm 0.77$ & 3.2 & $1505 \pm 75$ & 4.0 & $13.3 \pm 1.2$ & 7.0 \\
\hline S5 & $6.12 \pm 0.24$ & 3.2 & $0.99 \pm 0.10$ & 8.1 & $25.4 \pm 1.3$ & 4.0 & $1687 \pm 98$ & 4.7 & $26.2 \pm 2.0$ & 6.2 \\
\hline S6 & $3.66 \pm 0.31$ & 7.0 & $4.50 \pm 0.44$ & 7.8 & $13.01 \pm 0.79$ & 4.9 & $1005 \pm 37$ & 3.0 & $9.65 \pm 0.60$ & 5.0 \\
\hline Average & $4.31 \pm 0.28$ & 5.7 & $2.09 \pm 0.19$ & 7.8 & $20.0 \pm 1.1$ & 4.3 & $1273 \pm 70$ & 4.5 & $16.8 \pm 1.1$ & 5.0 \\
\hline
\end{tabular}

Working electrode: HMDE; RSD relative standard deviation; confidence intervals calculated on the significance level $\alpha=0.05$ 
were divided into three groups, according to parameters for their voltammetric determination (completely described in "Experimental" part):

(1) Cadmium, lead, copper (ASV, $\left.E_{\text {acc }}=-800 \mathrm{mV}\right)$;

(2) Zinc (ASV, $E_{\text {acc }}=-1200 \mathrm{mV}$ );

(3) Nickel (DMG complex, CSV, $E_{\text {acc }}=-500 \mathrm{mV}$ ).

Each determination was repeated five times. The anodic peak potentials $\left(E_{\mathrm{p}}\right)$ of determined metals were registered at: $E_{\mathrm{p}}(\mathrm{Cd})=-600 \mathrm{mV} ; E_{\mathrm{p}}(\mathrm{Pb})=-400 \mathrm{mV} ; E_{\mathrm{p}}(\mathrm{Cu})=+10 \mathrm{mV}$, $E_{\mathrm{p}}(\mathrm{Zn})=-1000 \mathrm{mV}$. In case of $\mathrm{Ni}$, single cathodic peak was registered at $E_{\mathrm{p}}(\mathrm{Ni})=-1020 \mathrm{mV}$. This peak corresponded to the reduction in $\mathrm{Ni}^{2+}$ bound in complex with added dimethylglyoxime (DMG), adsorbed on the mercury drop surface. All potential values are related to $\mathrm{Ag}|\mathrm{AgCl}| \mathrm{KCl}$ (sat.) reference electrode.

Contents of lead and cadmium in all analyzed bee venom samples were on the level of $\mathrm{mg} \mathrm{kg}^{-1}$, contents of nickel and copper were about ten times higher and content of zinc was on the level of $\mathrm{g} \mathrm{kg}^{-1}$ (Table 2). The average relative standard deviation (RSD) was 5.4\% (from 3.2 to $8.6 \%$ ).

\section{Determination of heavy metals using PLA-C electrode}

Mineralizates prepared by the above-described optimized digestion procedure were further analyzed on a working electrode prepared from PLA filament with carbon conductive admixture (PLA-C) with an active diameter of $1.75 \mathrm{~mm}$. At the start of every day or if the repeatability of the recorded signal worsened, the filament surface was polished with P600 sandpaper, rinsed with distilled water and then polished on polishing cloth with alumina suspension $\left(\mathrm{Al}_{2} \mathrm{O}_{3},<1.1 \mu \mathrm{m}\right.$, Sigma-Aldrich, Czech Republic). The measurements realized using PLA-C electrode are more complicated due to necessity to activate and electrochemically clean its surface. After each polishing process or any pause longer than $1 \mathrm{~h}$, the PLA-C electrode surface was activated by insertion of activation potential of $+2400 \mathrm{mV}$ for $180 \mathrm{~s}$. Pretreatment potential of $+1000 \mathrm{mV}$ was inserted for $60 \mathrm{~s}$ before each measurement set, as described by Vaneckova et al. [29].

The results of heavy metal determinations at PLA-C electrode are summarized in Table 3. The metals were divided into three groups (same as at HMDE, complete parameters are in "Experimental" section):

(1) Cadmium, lead, copper (ASV, $E_{\text {acc }}=-1200 \mathrm{mV}$ );

(2) Zinc (ASV, $E_{\text {acc }}=-1800 \mathrm{mV}$ );

(3) Nickel (DMG complex, ASV, $E_{\text {acc }}=-1400 \mathrm{mV}$ ).

The sensitivity of the PLA-C filament electrode is lower than that of HMDE. The anodic peak potentials were shifted to more negative potentials than those recorded at HMDE: $E_{\mathrm{p}}(\mathrm{Cd})=-780 \mathrm{mV} ; E_{\mathrm{p}}(\mathrm{Pb})=-570 \mathrm{mV}$; $E_{\mathrm{p}}(\mathrm{Cu})=-100 \mathrm{mV}, E_{\mathrm{p}}(\mathrm{Zn})=-1040 \mathrm{mV}$. It is not necessary to add gallium ions for the determination of zinc ions at PLA-C electrode, since the analysis is not influenced by the formation of intermetallic compounds with mercury. Similarly, as in the case of HMDE, complex with DMG was used for determination of Ni. However, the cathodic peak corresponding to reduction of $\mathrm{Ni}^{2+}$ bound in the complex with DMG (at about $-500 \mathrm{mV}$ ) wasn't sufficiently developed. Another nickel oxidation peak (at about $+830 \mathrm{mV}$, corresponding to oxidation of $\mathrm{Ni}^{2+}$ to $\mathrm{Ni}^{3+}$ ions bound in complex with DMG) [34] was used instead.

Contents of lead and cadmium in all analyzed bee venom samples were on the level of $\mathrm{mg} \mathrm{kg}^{-1}$, contents of nickel and copper were about ten times higher and content of zinc was on the level of $\mathrm{g} \mathrm{kg}^{-1}$ (Table 3). The results were obtained with average RSD $11.8 \%$ (from 6.5 to $18.0 \%$ ).

\section{Statistical analysis of results}

To compare the results achieved at HMDE and PLA-C electrode, respectively, as the working electrodes, the following statistical tests were used: $F$ test of equality of variances;

Table 3 Concentrations of heavy metals in honey bee venom; five times repeated determinations

\begin{tabular}{|c|c|c|c|c|c|c|c|c|c|c|}
\hline & $\mathrm{Pb} / \mathrm{mg} \mathrm{kg}^{-1}$ & RSD/\% & $\mathrm{Cd} / \mathrm{mg} \mathrm{kg}^{-1}$ & RSD/\% & $\mathrm{Cu} / \mathrm{mg} \mathrm{kg}^{-1}$ & $\mathrm{RSD} / \%$ & $\mathrm{Zn} / \mathrm{mg} \mathrm{kg}^{-1}$ & $\mathrm{RSD} / \%$ & $\mathrm{Ni} / \mathrm{mg} \mathrm{kg}^{-1}$ & $\mathrm{RSD} / \%$ \\
\hline $\mathrm{S} 1$ & $5.21 \pm 0.54$ & 8.4 & $3.14 \pm 0.46$ & 12 & $25.7 \pm 3.8$ & 12 & $1100 \pm 140$ & 10.0 & $18.1 \pm 1.4$ & 6.5 \\
\hline $\mathrm{S} 2$ & $4.30 \pm 0.49$ & 9.2 & $2.45 \pm 0.55$ & 18 & $23.2 \pm 2.7$ & 9.5 & $990 \pm 110$ & 9.1 & $20.8 \pm 3.2$ & 12 \\
\hline S3 & $3.21 \pm 0.48$ & 12 & $0.430 \pm 0.085$ & 16 & $15.3 \pm 3.4$ & 18 & $1240 \pm 220$ & 14 & $11.3 \pm 2.1$ & 18 \\
\hline S4 & $3.61 \pm 0.67$ & 15 & $0.320 \pm 0.072$ & 18 & $16.9 \pm 3.1$ & 15 & $1520 \pm 160$ & 8.6 & $14.6 \pm 2.2$ & 12 \\
\hline S5 & $6.29 \pm 0.63$ & 8.1 & $1.02 \pm 0.11$ & 8.3 & $21.6 \pm 3.8$ & 14 & $1440 \pm 240$ & 13 & $21.3 \pm 3.6$ & 14 \\
\hline S6 & $3.04 \pm 0.53$ & 14 & $4.54 \pm 0.63$ & 11 & $12.2 \pm 1.1$ & 7.3 & $895 \pm 84$ & 7.6 & $9.7 \pm 1.4$ & 11 \\
\hline Average & $4.28 \pm 0.56$ & 11 & $1.98 \pm 0.32$ & 14 & $19.2 \pm 3.0$ & 13 & $1200 \pm 160$ & 10 & $15.9 \pm 2.4$ & 12 \\
\hline
\end{tabular}

Working electrode: PLA-C; confidence intervals calculated on the significance level $\alpha=0.05$ 
independent two-sample $t$ test, equal sample sizes and variance; independent two-sample $t$ test, equal or unequal sample sizes, similar variances; two-sample Kolmogorov-Smirnov test and dependent $t$ test for paired samples. The null hypothesis $\mathrm{H}_{0}$ assuming that the results achieved using both working electrodes differ, was tested. The calculated statistical probabilities are summarized in Table 4. All calculated statistical probabilities are higher than 0.05 . Therefore, it is not possible to accept $\mathrm{H}_{0}$ hypothesis and it can be concluded that in case of all determined metals $(\mathrm{Pb}, \mathrm{Cd}, \mathrm{Cu}, \mathrm{Zn}, \mathrm{Ni})$ in honey bee venom mineralizates, the results achieved using HMDE are equivalent to those achieved using PLA-C filament as the working electrode.

\section{Conclusions}

New voltammetric method for determination of heavy metals in honey bee venom was developed. Prior to the voltammetric analysis itself, it was necessary to carry out wet digestion at elevated pressure and temperature $\left(140{ }^{\circ} \mathrm{C}\right)$ in the presence of concentrated oxidizing acids (nitric and sulfuric) for $4 \mathrm{~h}$. The mineralizate had to be subsequently repeatedly $(10-15 \times)$ dissolved in those acids and evaporated to dryness.

The results achieved using both HMDE and PLA-C electrode in mineralized samples of bee venom proved to be equivalent with the probability $(p<0.05)$ in case of all determined heavy metals $(\mathrm{Cd}, \mathrm{Pb}, \mathrm{Cu}, \mathrm{Zn}, \mathrm{Ni})$. The confidence intervals calculated from five times repeated determinations using both electrodes overlapped $(p<0.05)$ in the case of all metals. Moreover, the results of samples $\mathbf{S 1}$ were equivalent to those of $\mathbf{S} 2$ in case of all five determined heavy metals $(p<0.05)$ using HMDE as well as PLA-C filament. The same was valid for the results of the samples $\mathbf{S 3}$ and $\mathbf{S 4}$ $(p<0.05)$. Therefore, the analyzed samples can be divided into 4 groups $\mathbf{S 1}$ and $\mathbf{S 2} ; \mathbf{S 3}$ and $\mathbf{S 4}$; $\mathbf{S 5}$; and $\mathbf{S 6}$ (according to the found levels of metals). Nevertheless, found levels of particular metals in all analyzed samples were in one order (see Tables 2 and 3).
The confidence intervals calculated in case of results achieved using PLA-C filament were broader than those in case of HMDE (the same is valid for RSDs (11.8\% (from 6.5 to $18.0 \%$ ) vs. $5.4 \%$ (from 3.2 to $8.6 \%$ ) - the smallest in cases of $\mathrm{Cu}$ and $\mathrm{Zn}$, the largest case of $\mathrm{Cd}$ ).

The realized experiments confirmed that the determination at HMDE exhibits higher sensitivity, lower limits of detection, and requires shorter time of analysis. The PLA-C filament required a slightly longer time of analysis, but is fully sufficient for the determination of lead, cadmium, copper, nickel (concentration ranges of $\mathrm{mg} \mathrm{kg}^{-1}$ ), and zinc $(\mathrm{g}$ $\mathrm{kg}^{-1}$ ). Slightly longer experimental times at PLA-C are, however, negligible in comparison to the overall digestion time. The PLA-C electrode was proved to be a suitable alternative to HDME for ultratrace analysis of selected heavy metals in environmentally relevant samples.

\section{Experimental}

\section{Apparatus}

The computer-controlled Eco-Tribo Polarograph PC ETP with accessories (Polaro-Sensors, Prague) controlled by software Multielchem v. 3.3 for Windows 10 (J. Heyrovský Institute of Physical Chemistry) was used for voltammetric measurements with the pen-type HMDE (PolaroSensors, Prague, drop formation time $0.2 \mathrm{~s}$, capillary diameter $0.4 \mathrm{~mm}$ ). Potentiostat PalmSens 4 controlled by PSTrace 5 software (both PalmSens, The Netherlands) was used for experiments with PLA/C filament. In both cases, $\mathrm{Ag} \mid \mathrm{AgCl} \mathrm{KCl}($ sat.) electrode (Monokrystaly, Czech Republic) was used as reference electrode and platinum plate (1 $\mathrm{cm}^{2}$ ) as auxiliary electrode.

\section{Honey bee venom}

Samples of bee venom were supplied by the Food Research Institute Prague (Czech Republic). The samples were obtained in following manner: honey bees were placed in a box with inner glass walls coated with nonlubricated

Table 4 Statistical tests of equity of results achieved using pen-type HMDE and PLA-C, respectively, as working electrode

\begin{tabular}{|c|c|c|c|c|c|}
\hline & $\mathrm{p}(\mathrm{Pb})$ & $\mathrm{p}(\mathrm{Cd})$ & $\mathrm{p}(\mathrm{Cu})$ & $\mathrm{p}(\mathrm{Zn})$ & $\mathrm{p}(\mathrm{Ni})$ \\
\hline$F$ test of equality of variances & 0.309 & 0.445 & 0.095 & 0.135 & 0.086 \\
\hline Independent two-sample $t$ test, equal sample sizes and variance & 0.827 & 0.803 & 0.430 & 0.248 & 0.525 \\
\hline $\begin{array}{l}\text { Independent two-sample } t \text { test, equal or unequal sample sizes, similar } \\
\text { variances }\end{array}$ & 0.827 & 0.803 & 0.431 & 0.248 & 0.525 \\
\hline Two-sample Kolmogorov-Smirnov test & $>0.050$ & $>0.050$ & $>0.050$ & $>0.050$ & $>0.050$ \\
\hline Dependent $t$ test for paired samples & 0.373 & 0.267 & 0.250 & 0.104 & 0.209 \\
\hline
\end{tabular}

$\mathrm{p}(\mathrm{M})$ denotes probability of different results 
condoms. After irritation with ultrasound, the bees stung through the condom and the venom settled on the glass surface. After evaporation of the water, the dry venom was scraped with a razor blade into a container and analyzed. It was necessary to use approximately 100,000 bees to obtain $1 \mathrm{~g}$ of bee venom. Samples S1/S2; apparently originated from similar areas, just as $\mathbf{S 3 / \mathbf { S } 4}$ did. No additional information on the samples (e.g., tested region or its size) was provided to us.

\section{Sample digestion}

Wet digestion was performed in mineralizer "Laboratory equipment ZA-1 for pressure decomposition of samples" (Polaro Sensors, Czech Republic) with a strengthened inner Teflon container $(1 \mathrm{~cm})$. Sulfuric acid, $95-98 \%$, p.a., fuming nitric acid, $100 \%$, p.a., and hydrofluoric acid, $48 \%$ p.a., (all Sigma-Aldrich, Czech Republic) were used. Deionized water (Millipore, 18.2 M 2 ) was used for preparation of all solutions.

\section{Voltammetric determination of heavy metals in honey bee venom}

\section{Determination of selected heavy metals using HMDE}

Determinations using HMDE as the working electrode were realized in three groups [12] $\left(E_{\text {acc }}-\right.$ accumulation potential; $t_{\text {acc }}$-accumulation time; $t_{\text {rest }}$-rest time; $E_{\text {in }}$-initial potential; $E_{\text {fin }}$-final potential; $\nu$-scan rate; $H_{\text {pulse }}$-pulse high; $t_{\text {pulse }}$-pulse duration; $E_{\text {fin }}$-final potential):

(a) cadmium, lead, copper: $E_{\text {acc }}=E_{\text {in }}=-800 \mathrm{mV}$; $E_{\text {fin }}=+200 \mathrm{mV} ; t_{\mathrm{acc}}=0-60 \mathrm{~s} ; t_{\text {rest }}=15 \mathrm{~s}$; $\nu=20 \mathrm{mV} \mathrm{s}^{-1} ; H_{\text {pulse }}=50 \mathrm{mV} ; t_{\text {pulse }}=0.1 \mathrm{~s}$; sample solution acidified by $\mathrm{HCl}$ to $\mathrm{pH}=1$;

(b) zinc: $E_{\text {acc }}=E_{\text {in }}=-1200 \mathrm{mV} ; t_{\text {acc }}=0-10 \mathrm{~s} ; t_{\text {rest }}=10 \mathrm{~s}$; $E_{\text {fin }}=-800 \mathrm{mV} ; \nu=20 \mathrm{mV} \mathrm{s}^{-1} ; H_{\text {pulse }}=50 \mathrm{mV}$; $t_{\text {pulse }}=0.1 \mathrm{~s} ; 100 \mathrm{~mm}^{3} \mathrm{Ga}^{3+}\left(10 \mathrm{mg} \mathrm{cm}^{-3}\right)$ to the total volume of $10 \mathrm{~cm}^{3} ; \mathrm{pH}=4$;

(c) nickel: $E_{\text {acc }}=E_{\text {in }}=-500 \mathrm{mV} ; t_{\text {acc }}=10-15 \mathrm{~s} ; t_{\text {rest }}=10 \mathrm{~s}$; $E_{\text {fin }}=-1500 \mathrm{mV} ; \nu=20 \mathrm{mV} \mathrm{s}^{-1} ; H_{\text {pulse }}=50 \mathrm{mV}$; $t_{\text {pulse }}=0.1 \mathrm{~s} ; 0.2 \mathrm{~cm}^{3}$ conc. $\mathrm{NH}_{3}, 0.1 \mathrm{~g}$ of $\mathrm{NH}_{4} \mathrm{Cl}+0.1$ $\mathrm{cm}^{3}$ of $0.1 \%$ DMG to the total volume of $10 \mathrm{~cm}^{3} ; \mathrm{pH}=$ 8.9.

All chemicals, including hydrochloric acid, dimethylglyoxime (DMG), 99\%, acetic acid p.a., boric acid, ultrapure, and sodium hydroxide, p.a., gallium nitrate, p.a., and ammonium hydroxide, $99.99 \%$, were purchased from SigmaAldrich, Czech Republic.
Determination of selected heavy metals using PLA-C

PLA-C (Ø $1.75 \mathrm{~mm}$, declared resistivity $15 \Omega \mathrm{cm})$ was manufactured by Gembird, The Netherlands. In addition to standard PLA, it contains carbon black, which ensures sufficient conductivity. An approximately $5-\mathrm{cm}$ long filament was insulated along its entire length with a K32-2 shrink tube (GM Electronic, Czech Republic) and its uncovered bottom disk cross section with the diameter of $1.75 \mathrm{~mm}$ was used for the voltammetric experiments. The PLA-C surface was polished with $3 \mathrm{M} 401 \mathrm{Q}$ sandpaper, rinsed with distilled water, polished using an alumina suspension $\left(\mathrm{Al}_{2} \mathrm{O}_{3},<1.1 \mu \mathrm{m}\right.$, Sigma-Aldrich, Czech Republic) and then activated by insertion of voltage of $+2400 \mathrm{mV}$ for $180 \mathrm{~s}$. This procedure had to be repeated at the start of every day or if the repeatability of the recorded signal worsened. The experiments with the use of PLA-C electrode are more complicated due to necessity to activate and electrochemically clean its surface. After each polishing process or any pause longer than $1 \mathrm{~h}$, the electrode surface was activated by insertion of activation potential of $+2400 \mathrm{mV}$ for $180 \mathrm{~s}$. Moreover, it is necessary to insert potential $+1000 \mathrm{mV}$ for $60 \mathrm{~s}$ before each measurement set. The pretreatment and activation procedure was adopted according to the study by Vaneckova et al. [29].

Similarly, as in the case of HMDE, the determinations at PLA-C filament were realized in three groups [12, 34]:

(a) cadmium, lead, copper: $E_{\text {acc }}=E_{\text {in }}=-1200 \mathrm{mV}$; $t_{\mathrm{acc}}=120 \mathrm{~s} ; t_{\text {rest }}=2 \mathrm{~s} ; E_{\mathrm{fin}}=+200 \mathrm{mV} ; \nu=20 \mathrm{mV} \mathrm{s}^{-1}$; $H_{\text {pulse }}=50 \mathrm{mV} ; t_{\text {pulse }}=0.1 \mathrm{~s} ; 1 \mathrm{M}$ acetate buffer of $\mathrm{pH}=4.5$;

(b) zinc: $E_{\text {acc }}=E_{\text {in }}=-1600 \mathrm{mV} ; E_{\text {fin }}=-800 \mathrm{mV}$; $t_{\text {acc }}=15-30 \mathrm{~s} ; t_{\text {rest }}=2 \mathrm{~s} ; \nu=20 \mathrm{mV} \mathrm{s}^{-1} ; H_{\text {pulse }}=50 \mathrm{mV}$; $t_{\text {pulse }}=0.1 \mathrm{~s} ; 1 \mathrm{M}$ acetate buffer of $\mathrm{pH}=4.5$;

(c) nickel: $E_{\text {acc }}=E_{\text {in }}=-400 \mathrm{mV} ; t_{\text {acc }}=30-80 \mathrm{~s}, t_{\text {rest }}=2 \mathrm{~s}$; $E_{\text {fin }}=+1000 \mathrm{mV} ; \nu=20 \mathrm{mV} \mathrm{s}^{-1} ; H_{\text {pulse }}=50 \mathrm{mV}$; $t_{\text {pulse }}=0.1 \mathrm{~s}$; borate buffer, $0.1 \mathrm{~cm}^{3}$ of $0.1 \%$ DMG to the total volume of $10 \mathrm{~cm}^{3} ; \mathrm{pH}=8.2$.

\section{Statistical tests}

To compare the results achieved using both working electrodes [25], the following statistical tests were used: $F$ test of equality of variances, independent two-sample $t$ test, equal sample sizes and variance, independent two-sample $t$ test, equal or unequal sample sizes, similar variances, two-sample Kolmogorov-Smirnov test, and dependent $t$ test for paired samples. The calculations were performed using QC Expert v. 3.3 software (TriloByte, Czech Republic).

The other statistical calculations (averages, RSD, confidence intervals, etc.) were calculated using MS Excel 365 (Microsoft, USA). According to the current International 
Vocabulary of Metrology, there should be used the term "coverage interval" instead of "confidence interval". Nevertheless, due to more frequently used term "confidence interval" in analytical papers, we have it used too.

Acknowledgements The authors thank the project of Czech Science Foundation (GAČR No. 20-01589S) for financial support. Marta Choinska thanks Specific University Research (SVV260560).

\section{References}

1. Meier J, White J (1995) Handbook of clinical toxicology of animal venoms and poisons. Informa HealthCare, New York

2. Schumacher MJ, Tveten MS, Egen NB (1994) J Allergy Clin Immun 93:831

3. Haberman E (1972) Science 177:314

4. Comparative Toxicogenomics Database (2017) Adolapin. MDI Biological Laboratory and North Carolina State University. http:// ctdbase.org/detail.go?type $=$ chem $\&$ acc $=$ C034201. Accessed 29 Aug 2020

5. Lima WG, Brito JCM, da Cruz Nizer WS (2020). Phytother Res. https://doi.org/10.1002/ptr.6872

6. Evain L (2020) Future of food. J Food Agric Soc 8:79

7. Yang W, Hu FL, Xu XF (2020) Toxicon 181:69

8. Kumar V, Dhanjal JK, Bhargava P, Kaul A, Wang J, Zhang H, Kaul SC, Wadhwa R, Sundar D (2020). J Biomol Struct Dyn. https ://doi.org/10.1080/07391102.2020.1775704

9. Männle H, Hübner J, Münstedt K (2020) Toxicon 187:279

10. Ali H, Khan E (2018) Toxicol Environ Chem 100:6

11. Brezina M, Zuman P (1952) Polarography in medicine, biochemistry and pharmacy. Interscience Publishers, New York

12. Kopanica M, Navratil T, Sestakova I, Heyrovsky M (2010) Methods for Eco-Tribo Polarograph. Polaro-Sensors, spol. s r. o., Prague, p 99

13. Sestakova I, Navratil T (2005) Bioinorg Chem Appl 3:43

14. Navratil T, Novakova K, Josypcuk B, Sokolova R, Sestakova I (2016) Monatsh Chem 147:165

15. Sestakova I, Skalova S, Navratil T (2018) J Electroanal Chem 821:92

16. Navratil T, Sestakova I, Marecek V (2011) Int J Electrochem Sci 6:6032

17. Parisova M, Navratil T, Sestakova I, Jaklova Dytrtova J, Marecek V (2013) Int J Electrochem Sci 8:27
18. Novakova K, Navratil T, Sestakova I, Le MP, Vodickova H, Zamecnikova B, Sokolova R, Bulickova J, Gal M (2015) Monatsh Chem 146:819

19. Sestakova I, Navratil T, Josypcuk B (2016) Electroanalysis 28:2754

20. Mader P, Szakova J, Miholova D (1998) Analusis 26:121

21. Hynek D, Prasek J, Pikula J, Adam V, Hajkova P, Krejcova L, Trnkova L, Sochor J, Pohanka M, Hubalek J, Beklova M, Vrba R, Kizek R (2011) Int J Electrochem Sci 6:5980

22. Veverkova L, Hradilova S, Milde D, Panacek A, Skopalova J, Kvitek L, Petrzlova K, Zboril R (2014) Spectrochim Acta B 102:7

23. Cadkova Z, Szakova J, Miholova D, Horakova B, Kopecky O, Krivska D, Langrova I, Tlustos P (2015) J Agric Food Chem 63:2344

24. Mader P, Curdova E (1997) Chem Listy 91:227

25. Cizkova P, Navratil T, Sestakova I, Yosypchuk B (2007) Electroanalysis 19:161

26. Navratil T, Vlckova S, Mrazova K, Novakova K, Zakharov S, Honsova S, Pelclova D (2015) Information on several interesting case reports of liquid mercury intoxication. In: XXXV Moderni Elektrochemicke Metody (Modern Electrochemical Methods XXXV), p 156

27. Peckova K, Barek J, Navratil T, Yosypchuk B, Zima J (2009) Anal Lett 42:2339

28. Rathore M, Singh A, Pant VA (2012) Toxicol Int 19:81

29. Vaneckova E, Bousa M, Lachmanova SN, Rathousky J, Gal M, Sebechlebska T, Kolivoska V (2020) J Electroanal Chem $857: 113760$

30. Vaneckova E, Bousa M, Sokolova R, Moreno-Garcia P, Broekmann P, Shestivska V, Rathousky J, Gal M, Sebechlebska T, Kolivoska V (2020) J Electroanal Chem 858:113763

31. Vaneckova E, Bousa M, Vivaldi F, Gal M, Rathousky J, Kolivoska V, Sebechlebska T (2020) J Electroanal Chem 857:113760

32. Navratil T, Yosypchuk B, Barek J (2009) Chem Anal-Warsaw 54:3

33. Walters JG, Ahmed S, Rodriguez IMT, O'Neil GD (2020) Electroanalysis 32:859

34. Kanderal OM, Kozlowski H, Dobosz A, Swiatek-Kozlowska J, Meyer F, Fritsky IO (2005) Dalton Trans 8

Publisher's Note Springer Nature remains neutral with regard to jurisdictional claims in published maps and institutional affiliations.

\section{Authors and Affiliations}

\section{Marta Choinska ${ }^{1,2} \cdot$ Vojtěch Hrdlička $^{1}\left[\right.$ - Ivana Šestáková ${ }^{1}$. Tomáš Navrátil ${ }^{1}$}

1 J. Heyrovský Institute of Physical Chemistry of the Czech Academy of Sciences, Dolejškova 3, 18223 Prague 8, Czech Republic

2 Department of Analytical Chemistry, UNESCO Laboratory of Environmental Electrochemistry, Charles University,
Faculty of Science, Albertov 6, 12843 Prague 2,

Czech Republic 